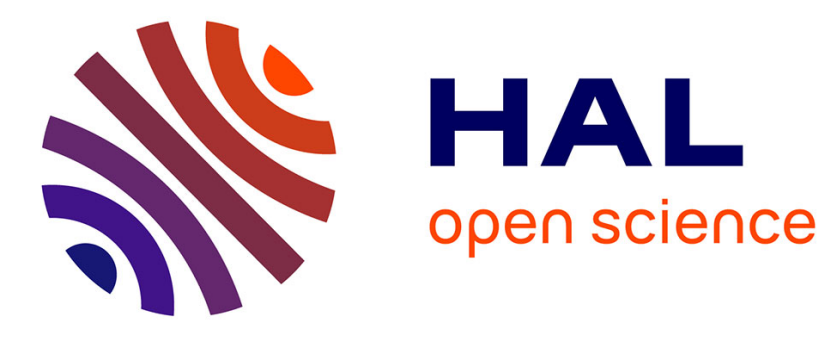

\title{
Long-term effect of fertilization on stone pine growth and cone production
}

Verónica Loewe-Muñoz, Claudia Delard, Rodrigo del Río, Mónica Balzarini

\section{To cite this version:}

Verónica Loewe-Muñoz, Claudia Delard, Rodrigo del Río, Mónica Balzarini. Long-term effect of fertilization on stone pine growth and cone production. Annals of Forest Science, 2020, 77 (3), pp.69. 10.1007/s13595-020-00978-6 . hal-03283599

\section{HAL Id: hal-03283599 https://hal.science/hal-03283599}

Submitted on 12 Jul 2021

HAL is a multi-disciplinary open access archive for the deposit and dissemination of scientific research documents, whether they are published or not. The documents may come from teaching and research institutions in France or abroad, or from public or private research centers.
L'archive ouverte pluridisciplinaire HAL, est destinée au dépôt et à la diffusion de documents scientifiques de niveau recherche, publiés ou non, émanant des établissements d'enseignement et de recherche français ou étrangers, des laboratoires publics ou privés. 


\title{
Long-term effect of fertilization on stone pine growth and cone production
}

\author{
Verónica Loewe-Muñoz ${ }^{1}$ (D) Claudia Delard ${ }^{1} \cdot$ Rodrigo Del Río $^{1} \cdot$ Mónica Balzarini $^{2}$
}

Received: 11 January 2020 / Accepted: 26 June 2020 / Published online: 8 July 2020

(C) INRAE and Springer-Verlag France SAS, part of Springer Nature 2020

\begin{abstract}
- Key message Fertilization is a feasible management technique for Pinus pinea $\mathrm{L}$. cropping, with increased cone production up to 9 years after the application and superior trunk diameter growth every year. Fertilization effects on cone size-weight indicate the value of re-fertilizing.

- Context Stone pine (Pinus pinea) is a species of economic interest for its highly in demand pine nuts. Despite the high value of pine nuts, cones are harvested mostly from non-managed forests. Consequently, advances in cropping techniques, such as fertilization, are needed.

- Aims To monitor the effect of fertilization on growth and cone production during 10 years after fertilization, adjusted to soil characteristics, on a 16-year-old stone pine orchard.

- Methods A fertilization trial including fertilized and non-fertilized plots was established. Diameter (trunk and crown) and height were repeatedly measured in each tree for 10 years. Cones were annually harvested from each tree and counted.

- Results Stone pine cone production increased significantly from the third to the ninth year of treatment, with a peak increase of 3.3 times.

- Conclusion Fertilization was a useful silvicultural practice to increase stone pine cone production. Periodical fertilization is recommended.
\end{abstract}

Keywords Stone pine $\cdot$ Fertilization $\cdot$ Cone production

\section{Introduction}

Handling Editor: Barry A. Gardiner

Contribution of the co-authors VL designed the study, directed the projects that funded the study, and wrote most of the paper. CD was in charge of measurements and field activities and contributed to the paper elaboration. RDR performed the statistical analysis, elaborated figures, and collaborated in information gathering and practical issues of the publication. MB designed, supervised, and significantly contributed to the paper discussion. All authors discussed the results and implications and commented on the manuscript at all stages.

Verónica Loewe-Muñoz

vloewe@infor.cl

Mónica Balzarini

mbalzari@gmail.com

1 Chilean Forest Institute (INFOR), Sucre 2397, Ñuñoa Santiago Chile

2 CONICET Biometry Unit, College of Agriculture, Universidad Nacional de Córdoba, Av. Haya de la Torre s/n Córdoba Argentina
Stone pine (Pinus pinea L.) is a valuable species for its delicious and highly nutritious edible seeds, the pine nuts or pinoli (Segura et al. 2006), the most expensive nut worldwide (INC 2018). Pine nuts are a good source of fat, proteins, vitamins (E, B6, niacin, folic acid), and a variety of phytochemicals, and contain high levels of potassium, phosphorus, magnesium, zinc, iron, and copper (Nergiz and Dönmez 2004; Evaristo et al. 2010; Bolling et al. 2011; Lutz et al. 2016). Despite the high value of pine nuts, specific cultivation techniques of stone pine as a fruit tree have been poorly developed, since cones are mostly harvested from natural forests (Mutke et al. 2012).

Stone pine is mostly distributed in coastal areas (Vendramin et al. 2008), which are considered one of the best sites for growth (Bussotti 1997; Campelo et al. 2007; Manzanera et al. 2016); in the coasts of Italy and Spain, soils are alluvial, volcanic (Costantini et al. 2004), or littoral dunes (Muñoz and Gracía 2009; Piraino et al. 2012). However, 
along the coastal areas of southern Latin America, P. pinea has been planted frequently on poor, light textured soils, with mineral deficiencies, usually of boron and phosphorus (IRENCORFO 1964; INTA 2018). The reported variation in diameter and height growth between and within plantations confirms that growth of this species is sensitive to soil conditions (Court-Picon et al. 2004; Mutke et al. 2007; Loewe-Muñoz et al. 2019a). Evaristo et al. (2010) reported significant differences in the mineral profile of pine nuts grown in different regions, suggesting that environment, and particularly soil types, could have an important influence. In the Southern Hemisphere, Vanhanen and Savage (2013) also reported variability in minerals probably related to soil type and nutritional status.

Fertilization is one of the most important management techniques to adjust soil nutrients, promoting growth and improving fruit yield and quality in fruit trees (Marschner 2012; Sansavini and Ranalli 2012). A positive impact of fertilization, especially in terms of nitrogen availability, has been reported for pines such as P. pinaster (Zas and Fernández-López 2005), $P$. edulis, and $P$. monophylla, with records of enhanced cone production (McLain 2008). Fertilization was shown to be a positive silvicultural practice in $P$. taeda, enhancing growth, even with low water availability (Maggard et al. 2016).

The short-term effect of fertilization on stone pine growth and fruiting was confirmed in an area of poor soil in Chile; after two consecutive years of fertilization, significant positive effects on diameter and height growth, as well as on 1-yearold conelet production, were observed (Loewe et al. 2017). However, unlike in other fruit tree species, long-term effects of fertilization on stone pine are unknown. Studies in this species are challenging because cone development takes 42 months from differentiation to harvest, and 1-, 2- and 3year-old cones occur simultaneously on the same tree, making the evaluation of any management practice more complex than in other species (Loewe et al. 2016). The known positive correlations of diameter at breast height (DBH) and crown diameter with cone number in stone pine suggest that, if vegetative growth increases as a consequence of fertilization, pine nut production may also increase. Long-term studies are needed to better understand the duration of fertilization effects on cone production (cone number and size-weight). This type of basic information is crucial to define the re-fertilization requirements of stone pine and fertilization management schedules.

Fertilization of soils with unbalanced mineral content is more complicated than that in sites of medium to high fertility (Kolari 1983). The effect of soil fertilization including nitrogen, phosphorus, and potassium is expected to be positive in forests with no deficiency of micronutrients, especially boron (Paavilainen 1990). The impact of micronutrients on stone pine has only been addressed by Bento and Coutinho (2011), and Malchi and Shenker (2011), who studied boron and iron deficit, respectively. Nutrient deficiency affects stone pine fruit production. In poor soils of the species' native area, nitrogen, phosphorus, calcium, and manganese depletion was positively correlated with needle and cone loss (Kilci et al. 2013). In Portugal, Freire et al. (2019) reported that the most productive stone pine stands (up to $6000 \mathrm{~kg}$ cones ha ${ }^{-1}$ year $^{-1}$ ) correspond to agroforestry systems associated with fertilized pastures, indicating the convenience of soil fertilization to obtain not only more cones, but also heavier ones. In Spain, Calama et al. (2007) monitored cone production and quality in an adult (50 year old) stone pine forest and found a positive response, although lower than expected, to fertilization with a high dose of dolomite (calcium magnesium carbonate); the authors suggested exploring the effects of nitrogen fertilizers.

To the best of our knowledge, no long-term studies monitoring the effect of fertilization on stone pine cone production have been published. The hypothesis to be tested was that fertilization of stone pine plantations, established on nutrient poor soils, would boost vegetative growth and cone production, but that this effect would not be long-lasting. The objective of this work was to monitor growth and production during several years after fertilization, adjusted to account for the existing nutritional status of the soil, on a 16 -year-old stone pine orchard.

\section{Material and method}

\subsection{Experimental trial}

The trial was conducted in a 2-ha, 16-year-old non-irrigated stone pine plantation located in Toconey $\left(35^{\circ} 24^{\prime} \mathrm{S}, 72^{\circ} 3^{\prime}\right.$ $\mathrm{W})$, Maule region, Chile, on smooth hills with soil of granitic origin. The climate in the region is typically Mediterranean, characterized by long dry summers and short and intense rainfalls in winters, with maritime influence given by the entrance of the Pacific Ocean fog into the valley through the Maule River. Average annual climate data (2009 to 2018) for Toconey shows rainfall of $630 \mathrm{~mm}$, evapotranspiration of $1451 \mathrm{~mm}, 8$ dry months year ${ }^{-1}$ [dry month $=($ monthly rainfall/monthly evapotranspiration $)<0.5$ ], and average temperature of $14.2{ }^{\circ} \mathrm{C}$ (www.dga.cl). The climatic variables related to stone pine productivity for the study period are summarized in Table 1 and were taken from Loewe et al. (2016).

A soil survey was conducted across the plantation area following a systematic zigzag pattern in three zones randomly located; at each sample point, soil from three depths (up to $60 \mathrm{~cm}$ ) was collected to build a composite sample. Soil analyses (Table 2) indicated that the trial site is on a silty, non-salty soil with neutral $\mathrm{pH}$, and medium organic matter content. Mineral composition showed a very low phosphorus, zinc, sulfur, and boron content; low calcium content; and medium 
Table 1 Climate variables influencing stone pine cone production in Toconey, Chile, during the study

\begin{tabular}{llllll}
\hline Year & $\begin{array}{l}\text { Annual rainfall } \\
(\mathrm{mm})\end{array}$ & $\begin{array}{l}\text { Annual thermal } \\
\text { oscillation } \dagger\left({ }^{\circ} \mathrm{C}\right)\end{array}$ & $\begin{array}{l}\text { Autumn thermal } \\
\text { oscillation }\left({ }^{\circ} \mathrm{C}\right)\end{array}$ & $\begin{array}{l}\text { Spring } \\
\text { rainfall }(\mathrm{mm})\end{array}$ & $\begin{array}{l}\text { Spring Hydric } \\
\text { Index } \dagger \dagger(\mathrm{mm})\end{array}$ \\
\hline 2009 & 689.0 & 16.2 & 14.6 & 66.4 & -385.3 \\
2010 & 566.0 & 16.4 & 15.9 & 28.9 & -441.8 \\
2011 & 631.0 & 15.4 & 13.6 & 15.8 & -435.2 \\
2012 & 543.0 & 15.2 & 14.1 & 82.4 & -333.5 \\
2013 & 508.0 & 16.6 & 15.9 & 26.4 & -455.2 \\
2014 & 839.0 & 15.9 & 13.8 & 41.1 & -379.1 \\
2015 & 691.3 & 13.9 & 12.9 & 130.9 & -285.7 \\
2016 & 484.0 & 14.1 & 10.9 & 71.3 & -398.0 \\
2017 & 808.0 & 14.4 & 12.9 & 95.2 & -343.9 \\
2018 & 543.0 & 14.7 & 14.1 & 83.3 & -367.7 \\
Average & 630.2 & 15.3 & 13.9 & 64.2 & \\
\hline
\end{tabular}

$\dagger$ Thermal oscillation: average maximum absolute temperature minus average minimum absolute temperature for a given period expressed in degrees Celsius

$\dagger \dagger$ Hydric index, an indicator of water deficit, HI: rainfall minus potential evapotranspiration, expressed in mm

nitrogen, potassium, magnesium, copper, iron, and manganese content.

In winter 2009, before the start of the assay, management practices were applied homogeneously with the aim of obtaining a strong, well-formed, productive tree crown in the orchard. Trees were trained with one main leader and the trunk hand-pruned on the lower three meters, removing all lateral branches. A thinning was applied in the orchard, which consisted of cutting down $50 \%$ of trees, leaving on average 204 trees/ha. Two treatments were established, involving

Table 2 Soil properties at the trial site (Toconey, Chile)

\begin{tabular}{|c|c|c|}
\hline Property & Toconey site & Method \\
\hline Texture $(\%)$ & & Bouyoucos soil hydrometer (USDA 2004) \\
\hline Sand & $29 \pm 0.00$ & \\
\hline Lime & $45 \pm 0.00$ & \\
\hline Clay & $26 \pm 0.00$ & \\
\hline $\mathrm{pH}$ & $6.03 \pm 0.18$ & $\begin{array}{l}\text { Glass electrode ph meter (1:2.5 soil to water suspension) } \\
\text { (Sadzawaka et al. 2006) }\end{array}$ \\
\hline Salinity, EC (mmhos $\left.\mathrm{cm}^{-1}\right)$ & $0.04 \pm 0.00$ & $\begin{array}{l}\text { Electrical conductivity of the saturated paste extract } \\
\text { (1:1 soil to water) (Sadzawaka et al. 2006) }\end{array}$ \\
\hline Organic matter $(\%)$ & $2.27 \pm 0.18$ & Oxidation and colorimetry (Sadzawaka et al. 2006) \\
\hline \multicolumn{3}{|l|}{ Nutrient content } \\
\hline $\mathrm{N}\left(\mathrm{mg} \mathrm{kg}^{-1}\right)$ & $21.33 \pm 6.06$ & Extraction with kcl $2 \mathrm{~mol} \mathrm{l}^{-1}$ (Sadzawaka et al. 2006) \\
\hline $\mathrm{P}\left(\mathrm{mg} \mathrm{kg}^{-1}\right)$ & $3.33 \pm 0.88$ & Extraction with nahco $30.5 \mathrm{~mol} \mathrm{l}^{-1}$ at ph 8.0 (Sadzawaka et al. 2006) \\
\hline $\mathrm{K}\left(\mathrm{mg} \mathrm{kg}^{-1}\right)$ & $91.33 \pm 11.10$ & Extraction with $\mathrm{nh}_{4} \mathrm{ch}_{3} \mathrm{Co}_{2} 1 \mathrm{~mol} \mathrm{l}^{-1}$ at ph 7.0 (Sadzawaka et al. 2006) \\
\hline $\mathrm{Ca}$ exch $\left(\mathrm{cmol}+\mathrm{kg}^{-1}\right)$ & $88.03 \pm 85.48$ & Extraction with $\mathrm{nh}_{4} \mathrm{ch}_{3} \mathrm{Co}_{2} 1 \mathrm{~mol} \mathrm{l}^{-1}$ at ph 7.0 (Sadzawaka et al. 2006) \\
\hline $\mathrm{Mg}$ exch $\left(\mathrm{cmol}+\mathrm{kg}^{-1}\right)$ & $0.79 \pm 0.02$ & Extraction with $\mathrm{c} \mathrm{nh}_{4} \mathrm{ch}_{3} \mathrm{co}_{2} 1 \mathrm{~mol} \mathrm{l}^{-1}$ at ph 7.0 (Sadzawaka et al. 2006) \\
\hline $\mathrm{Cu}\left(\mathrm{mg} \mathrm{kg}^{-1}\right)$ & $0.50 \pm 0.15$ & Extraction with dtpa (diethylenetriaminepentaacetic acid) (Sadzawaka 1990) \\
\hline $\mathrm{Zn}\left(\mathrm{mg} \mathrm{kg}^{-1}\right)$ & $0.22 \pm 0.05$ & Extraction with dtpa (diethylenetriaminepentaacetic acid) (Sadzawaka 1990) \\
\hline $\operatorname{Mn}\left(\mathrm{mg} \mathrm{kg}^{-1}\right)$ & $16.47 \pm 7.03$ & Extraction with dtpa (diethylenetriaminepentaacetic acid) (Sadzawaka 1990) \\
\hline $\mathrm{Fe}\left(\mathrm{mg} \mathrm{kg}^{-1}\right)$ & $23.33 \pm 2.85$ & Extraction with dtpa (diethylenetriaminepentaacetic acid) (Sadzawaka 1990) \\
\hline $\mathrm{B}\left(\mathrm{mg} \mathrm{kg}^{-1}\right)$ & $0.31 \pm 0.10$ & Extraction with cacl $_{2}$ mol l$^{-1}$ (Sadzawaka 1990) \\
\hline $\mathrm{S}\left(\mathrm{mg} \mathrm{kg}^{-1}\right)$ & $<2$ & Extraction with ca $\left(\mathrm{h}_{2} \mathrm{po}_{4}\right)_{2} 0.01 \mathrm{~mol} \mathrm{l}^{-1}$ (Sadzawaka et al. 2006) \\
\hline
\end{tabular}


fertilized and non-fertilized plots, following a completely randomized design with six replicates for the former treatment and two replicates for the latter. The experimental units were plots of 25 and 10 trees for fertilization and non-fertilization treatments, respectively.

In spring 2009 (at plantation age of 16 years), fertilization was applied equally in all fertilized plots, including macronutrients (phosphorus, potassium, calcium, and sulfur) and micronutrients (boron and zinc) at rates determined according to the soil deficiencies identified through the soil analyses. Fertilizer was supplied at $260 \mathrm{~g}$ per tree, and was composed of phosphoric acid (60 g), calcium phosphate (60 g), zinc sulfate $(10 \mathrm{~g})$, sodium borate $(20 \mathrm{~g})$, potassium sulfate $(60 \mathrm{~g})$, and carbamide $(50 \mathrm{~g})$. Doses of the applied elements per tree were nitrogen (23 g), phosphorus (49 g), potassium (31 g), boron (4 g), zinc (2 g), calcium (12 g), sodium (2 g), and sulfur (18 g). Fertilizer was applied at $5 \mathrm{~cm}$ soil depth on two lateral strips located at the edge of the crown projection.

\subsection{Recorded data}

Growth was repeatedly measured in each tree during the 2009-2018 period; diameter at breast height (DBH) was recorded at $130 \mathrm{~cm}$ above the ground with a caliper (Haglöf, Långsele, Sweden) and tree height, with a hypsometer (Suunto, Vantaa, Finland). At the end of the study period, vigor was assessed in all trees using a categorical scale: (1) high vigor (abundant foliage, dark green needles), (2) medium vigor (abundant to regular foliage, light green to yellow needles), and (3) low vigor (scarce foliage, strong discoloration), based on Lakatos and Mirtchev (2014). All 3-year-old cones were annually harvested and counted in July from 2009 to 2018. Harvested cones were classified according to the following categorical scale: small $(<350 \mathrm{~g})$, medium (350$550 \mathrm{~g}$ ), and big (>550 g); 350 and $550 \mathrm{~g}$ were the first and third quartile, respectively, of the weight distribution, which was determined by a sample of 100 randomly selected cones. Analyses were performed using data from the 2012-2018 period to avoid the impact of management practices (pruning and thinning) applied at the beginning of the study.

Cone health was monitored in each harvested cone through visual observation; cones were classified as healthy (without any external damage) or damaged (presence of at least one of the following symptoms: holes, excessive accumulation of resin, deformations).

\subsection{Statistical analysis}

An ANOVA for repeated measurements was fitted for each variable using a model with the following terms: treatment effect, year effect, treatment $\times$ year interaction regarded as fixed effects, and a random plot effect. Normal distribution was assumed for the error terms of the models for height,
$\mathrm{DBH}$ and crown diameter, and a Poisson distribution for the total number of 3-year-old cones per tree and the number of mature cones in each cone weight category. Two new variables were created from the measurements of cone number tree $^{-1}$ : cone number per crown area $\left(\mathrm{C} / \mathrm{C}\right.$, cones $\left.\mathrm{m}^{-2}\right)$ and cone number per trunk diameter $\left(\mathrm{C} / \mathrm{DBH}\right.$, cones $\left.\mathrm{cm}^{-1}\right)$. DBH in 2009 was used as covariate to adjust for size variability among trees in all fitted ANOVA models. Tree vigor was analyzed through the percentage of high vigor trees per plot at the end of the study assuming a binomial distribution. Cone health was not statistically modeled because all cones were healthy. Statistical analyses were performed using the software InfoStat (Di Rienzo et al. 2019) and its interface with the software R (www.r-project.org) to assess statistical significance of each model effect in a generalized linear mixed model framework (Stroup 2012).

\section{Results}

\subsection{Growth}

The effect of treatment $\times$ year interaction was statistically significant for DBH $(p<0.05)$, but not for crown diameter or height $(p>0.05)$ (data not shown). The yearly mean comparisons showed that the only difference in growth corresponded to DBH 9 years after fertilizer application (see results in Table 3). Average $\mathrm{DBH}$ growth rates for the years 2012 to 2018 of fertilized plots were higher than those of the non-fertilized ones $\left(1.23 \mathrm{~cm}_{\text {year }}{ }^{-1}\right.$ vs $0.87 \mathrm{~cm}_{\text {year }}{ }^{-1}$, respectively) ( $p=0.0007)$. In the same period, crown diameter (CD) and total height of trees were higher in fertilized plots, but the effect was not statistically significant $(p>0.05)$.

At the end of the study period, no statistical differences were found for vigor between fertilized and non-fertilized trees, given that 90 to $95 \%$ of trees were classified as vigorous in all plots.

\subsection{Cone production}

The number of harvestable cones per tree showed a statistical significant increase in the fertilized trees between the third and ninth years after treatment, with a peak in the fifth year (2014) - when fertilized trees had 3.3 times more cones than non-fertilized ones (Table 3 and Fig. 3. in Annex). Cone number tree ${ }^{-1}$ showed synchronous variability over the years. When cone number tree ${ }^{-1}$ was expressed in relation to trunk diameter $(\mathrm{C} / \mathrm{DBH})$, the effects of the treatment $\times$ year interaction and of treatment were not statistically significant $(p>0.05)$ (Table 3). However, cone number tree ${ }^{-1}$ expressed as unit of crown area showed statistical differences among treatments 5 years after fertilization and at the end of the study $(p<0.05)$ (Table 3). 
Table 3 Stone pine growth and cone number for each treatment after 3 to 9 years of fertilization

\begin{tabular}{|c|c|c|c|c|c|c|c|c|c|}
\hline \multirow[t]{2}{*}{ Variable } & \multirow[t]{2}{*}{ Units } & \multirow[t]{2}{*}{ Treatment } & \multicolumn{7}{|l|}{ Year } \\
\hline & & & 2012 & 2013 & 2014 & 2015 & 2016 & 2017 & 2018 \\
\hline \multirow[t]{2}{*}{ DBH } & \multirow[t]{2}{*}[\mathrm{cm}]{} & Fertilized & $31.2 \pm 0.4 \mathrm{a}$ & $33.1 \pm 0.4 \mathrm{a}$ & $34.4 \pm 0.4 \mathrm{a}$ & $35.7 \pm 0.4 \mathrm{a}$ & $36.7 \pm 0.4 \mathrm{a}$ & $37.8 \pm 0.4 \mathrm{a}$ & $38.8 \pm 0.4 \mathrm{a}$ \\
\hline & & Non-fertilized & $30.5 \pm 1.0 \mathrm{a}$ & $32.4 \pm 1.0 \mathrm{a}$ & $33.1 \pm 1.0 \mathrm{a}$ & $34.8 \pm 1.0 \mathrm{a}$ & $35.6 \pm 1.0 \mathrm{a}$ & $35.9 \pm 1.0 \mathrm{a}$ & $36.2 \pm 1.0 \mathrm{~b}$ \\
\hline \multirow[t]{2}{*}{$\mathrm{CD}$} & \multirow[t]{2}{*}[\mathrm{m}]{} & Fertilized & $6.6 \pm 0.1 \mathrm{a}$ & $7.2 \pm 0.1 \mathrm{a}$ & $7.2 \pm 0.1 \mathrm{a}$ & $7.2 \pm 0.1 \mathrm{a}$ & $7.4 \pm 0.1 \mathrm{a}$ & $7.5 \pm 0.1 \mathrm{a}$ & $7.7 \pm 0.1 \mathrm{a}$ \\
\hline & & Non-fertilized & $6.3 \pm 0.3 \mathrm{a}$ & $7.1 \pm 0.3 \mathrm{a}$ & $7.1 \pm 0.3 \mathrm{a}$ & $7.1 \pm 0.3 \mathrm{a}$ & $7.1 \pm 0.3 \mathrm{a}$ & $7.2 \pm 0.3 \mathrm{a}$ & $7.3 \pm 0.3 \mathrm{a}$ \\
\hline \multirow[t]{2}{*}{ Height } & \multirow[t]{2}{*}[\mathrm{m}]{} & Fertilized & $11.9 \pm 0.2 \mathrm{a}$ & $12.7 \pm 0.2 \mathrm{a}$ & $12.7 \pm 0.2 \mathrm{a}$ & $12.7 \pm 0.2 \mathrm{a}$ & $13.6 \pm 0.2 \mathrm{a}$ & $14.5 \pm 0.2 \mathrm{a}$ & $15.4 \pm 0.2 \mathrm{a}$ \\
\hline & & Non-fertilized & $11.5 \pm 0.5 \mathrm{a}$ & $12.1 \pm 0.5 \mathrm{a}$ & $12.4 \pm 0.5 \mathrm{a}$ & $12.7 \pm 0.5 \mathrm{a}$ & $13.5 \pm 0.5 \mathrm{a}$ & $14.3 \pm 0.5 \mathrm{a}$ & $15.1 \pm 0.5 \mathrm{a}$ \\
\hline \multirow[t]{2}{*}{ Cones } & \multirow[t]{2}{*}[\#]{} & Fertilized & $4.83 \pm 0.9 \mathrm{a}$ & $14.6 \pm 2.6 \mathrm{a}$ & $14.0 \pm 2.5 \mathrm{a}$ & $9.8 \pm 1.8 \mathrm{a}$ & $10.1 \pm 1.8 \mathrm{a}$ & $20.1 \pm 3.6 \mathrm{a}$ & $17.8 \pm 3.2 \mathrm{a}$ \\
\hline & & Non-fertilized & $2.57 \pm 0.9 \mathrm{a}$ & $7.2 \pm 2.3 \mathrm{a}$ & $4.3 \pm 1.4 \mathrm{~b}$ & $3.9 \pm 1.3 \mathrm{~b}$ & $4.1 \pm 1.3 b$ & $9.5 \pm 3.0 \mathrm{~b}$ & $7.5 \pm 2.4 \mathrm{~b}$ \\
\hline \multirow[t]{2}{*}{$\mathrm{C} / \mathrm{DBH}$} & \multirow[t]{2}{*}[\#/\mathrm{cm}]{} & Fertilized & $0.18 \pm 0.08 \mathrm{a}$ & $0.50 \pm 0.08 \mathrm{a}$ & $0.45 \pm 0.08 \mathrm{a}$ & $0.30 \pm 0.08 \mathrm{a}$ & $0.31 \pm 0.08 \mathrm{a}$ & $0.62 \pm 0.08 \mathrm{a}$ & $0.55 \pm 0.08 \mathrm{a}$ \\
\hline & & Non-fertilized & $0.09 \pm 0.16 \mathrm{a}$ & $0.21 \pm 0.16 \mathrm{a}$ & $0.12 \pm 0.16 \mathrm{a}$ & $0.10 \pm 0.16 \mathrm{a}$ & $0.11 \pm 0.16 \mathrm{a}$ & $0.26 \pm 0.16 \mathrm{a}$ & $0.21 \pm 0.16 \mathrm{a}$ \\
\hline \multirow[t]{2}{*}{$\mathrm{C} / \mathrm{C}$} & \multirow[t]{2}{*}[\#/\mathrm{m}^{2}]{} & Fertilized & $0.16 \pm 0.05 \mathrm{a}$ & $0.38 \pm 0.05 \mathrm{a}$ & $0.35 \pm 0.05 \mathrm{a}$ & $0.24 \pm 0.05 \mathrm{a}$ & $0.24 \pm 0.05 \mathrm{a}$ & $0.48 \pm 0.05 \mathrm{a}$ & $0.42 \pm 0.05 \mathrm{a}$ \\
\hline & & Non-fertilized & $0.10 \pm 0.10 \mathrm{a}$ & $0.20 \pm 0.10 \mathrm{a}$ & $0.12 \pm 0.10 b$ & $0.10 \pm 0.10 \mathrm{a}$ & $0.11 \pm 0.10 \mathrm{a}$ & $0.25 \pm 0.10 b$ & $0.19 \pm 0.10 b$ \\
\hline
\end{tabular}

Mean \pm SEM. By year, among variables and treatments, different letters indicate statistical differences $(p<0.05)$

$D B H$, diameter at breast height $(1.3 \mathrm{~m}) ; C D$, crown diameter, defined as the width of the crown; Height, total tree height; Cones, all cones from each tree were manually harvested to ensure that the entire production was assessed; $C / C$, cone number per crown area (cones $\mathrm{m}^{-2}$ tree $^{-1}$ ); $C / D B H$, cone number per trunk diameter $\left(\right.$ cones $\mathrm{cm}^{-1}$ tree $\left.^{-1}\right)$

Regarding cone size-weight categories, the fertilization effect peaked 5 years after the intervention, declining thereafter. In fact, differences in percentage of big and medium cones between treatments were observed, with an increasing proportion of medium and small cones for the fertilized plots over time (Table 4 in Annex). Figure 1 depicts the differences in cone size-weight category distribution between 2014 and 2018. In 2014, the higher number of cones in fertilized plots was distributed in big and medium cones (Fig. 1 top). However, at the end of the study, fertilized plots had a higher number of cones than non-fertilized ones, but cone distribution by the size-weight category indicated a higher presence of small cones than 5 years after fertilization (Fig. 1 bottom).

The estimated cone production per hectare shows a difference of over $1500 \mathrm{~kg}$ between fertilized and non-fertilized plots in 2017, the bumper crop year (Fig. 2). Regarding cone health, all cones were classified as healthy.

\section{Discussion}

In our study, regarding vegetative growth, fertilized trees exhibited an increase in average diameter growth rates in years after treatment of over $40 \%$ with respect to nonfertilized trees, showing that fertilization has a positive effect on stone pine trunk diameter, as reported by Kilci et al. (2013). This positive effect of nutrient supplementation on a plantation established in a poor soil is consistent with the important nitrogen uptake reported for similar soils in a stone pine forest located in the coast of
France (Rapp et al. 1979). Reports for other pines, such as $P$. tropicalis, indicate that nutritional deficiencies affected diameter growth, with $\mathrm{P}$ being the main limiting nutrient (Ferrer et al. 2004); moreover, for $P$. radiata, boron deficiency was reported to limit growth, cause malformations, and inhibit fruiting (Schlatter and Gerding 1984). Low content of micronutrients, particularly of boron, might limit the expected effect of nitrogen supplementation on vegetative growth (Paavilainen 1990). However, the simultaneous supply of macro- and micronutrients in the studied plantation favored stem growth, even though the soil had a very low boron content. Contrary to findings reported by Ravazi et al. (2006), we did not find significant effects of fertilization on height growth or crown diameter, which could be due to the limited space available for crown expansion in the current average spacing $(7 \times 7 \mathrm{~m})$.

In order to promote adaptation to climate change, management practices oriented to achieve the highest possible tree vigor are desirable to reduce susceptibility to pathogen attacks and drought episodes. Moreover, vigor is correlated to number of female flowers or strobili (Mutke 2005). At the end of our study, 9 years after fertilization, there were no differences in vigor between fertilized and non-fertilized plots.

Cone production showed high variability throughout the years; this is a typical behavior of the species, which is characterized by a masting habit (Prades et al. 2005). The observed synchronicity of cone production throughout the study period, regardless of the nutritional status, suggests that this 


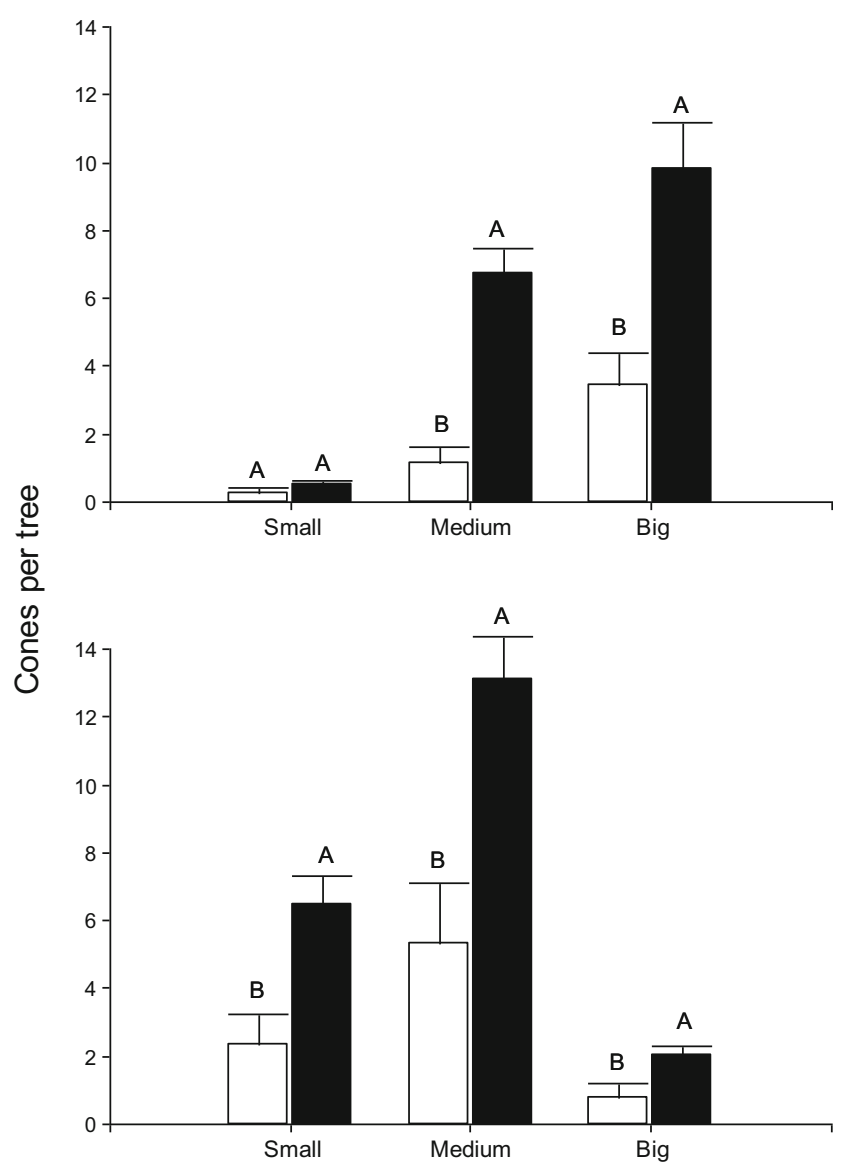

Fig. 1 Cones per tree and size-weight category in fertilized (black) and non-fertilized (white) trees five (2014) (top) and nine (2018) (bottom) years after fertilization in Toconey, central Chile. Different letters within a weight category indicate statistical differences between treatments in cone number per tree for that category $(p<0.05)$

variability is a response to climate conditions. Indeed, Calama et al. (2019) and Loewe et al. (2016) found that cone

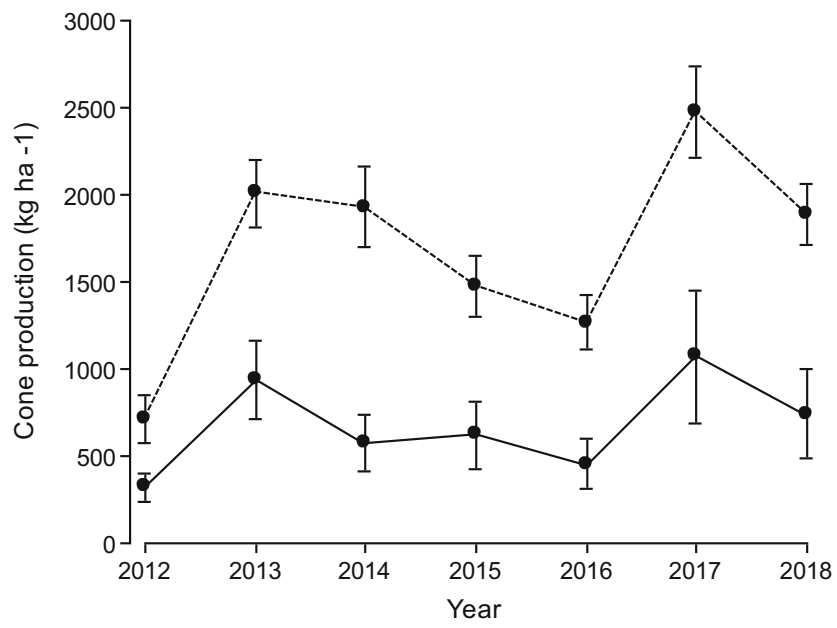

Fig. 2 Evolution of cone production per hectare in fertilized (dashed line) and non-fertilized (solid line) plots 3 to 9 years after fertilization (2012 to 2018 ) in a stone pine plantation located in Toconey, central Chile. Mean \pm SE production in Spain and Chile, respectively, was favored by an annual thermal oscillation below $12{ }^{\circ} \mathrm{C}$, among other climatic factors. This climatic condition does not occur in the study site, and would explain the lower cone production than in other areas of Chile (Loewe et al. 2016). Despite that interannual variability, our fertilized plots maintained a significantly higher production than non-fertilized ones. Other authors have reported that early spring fertilization would favor female cone induction in P. elliotti (Hoekstra and Mergen 1957; Shoulders 1968), and male cone production for $P$. radiata (Codesido and Merlo 2007).

A positive impact of the tested spring fertilization applied in 3-year-old cone number tree ${ }^{-1}$ in 2009 was observed in the successive harvests from 2014, 5 years after treatment, when cone production due to fertilization was up to 3.3 times higher than in the non-fertilized plots. Our results showed a higher impact of nutrient supplementation than that reported by Kilci et al. (2013), who found that a higher dose of macronutrient fertilization (2360 $\mathrm{g} \mathrm{tree}^{-1}$ ) than the one used in this work ( $260 \mathrm{~g} \mathrm{tree}^{-1}$ ) resulted in a 1.4 times higher cone production than in the non-fertilized trees. The lower values obtained by Kilci et al. (2013) may be attributed to the deficiency of some micronutrients, as reported by Paavilainen (1990).

Cone production, expressed as number of cones/tree, in the first two harvests after fertilization (2012 and 2013) was not statistically significant in our study, probably because of the heavy pruning performed in 2009; indeed, $50 \%$ of the crown of many trees was extracted by removing low trunk bifurcations. After the restoration of crowns in all trees, verified after 2 years (Loewe et al. 2013), the impact of nutrient supplementation became significant and was maintained in the following harvests.

The analysis of the cone number/DBH ratio showed no significant differences between treatments over the years. The analysis in relation to crown area indicates that, also starting 5 years after the management practice and except for 2 years of low production (2015 and 2016), fertilization had a significant positive effect on cone production, enhancing the productive potential of the tree crown. Regarding cone health, we did not find differences between fertilized and nonfertilized plots; this result is in disagreement with findings of Farinha et al. (2018), who reported that cones from stone pine trees fertilized through the irrigation system are more susceptible to conelet mortality and seed damage by Leptoglossus occidentalis.

Although fertilization increased cone production, it did not reduce cone size-weight for 5 years after treatment, with a significant increase in medium and big cones being observed. However, at the end of the study period, the distribution of cone size-weight was skewed toward the smaller cones. Kilci et al. (2016) also reported changes in cone weight distribution in response to fertilization. Therefore, given that the effect of fertilization is not 
long-lasting, periodical fertilization might be necessary to enhance cone number and size-weight, as previously reported by Calama et al. (2007), Kilci et al. (2013) and Loewe et al. (2017). Thus, re-fertilization would be necessary to obtain high cone production concentrated in bigger cones, thereby improving fruit quality (Calama et al. 2007; Freire et al. 2019). Nevertheless, a recent study concluded that pine nut production depends not only on cone number but also on pine nut number inside cones and pine nut weight (Loewe-Muñoz et al. 2019b), with number of pine nuts per cone being the most important fruit trait in determining pine nut yield. Consequently, further studies are needed to determine the effect of re-fertilization on pinoli production.

The strong and long-lasting effect of fertilization on cone number is undoubtedly a positive factor for productive stone pine stands established in silty soils of granitic origin. However, after 5 years of fertilizer supplementation, the gain in cone production decreased, which also indicates the need for repeating fertilization to enhance cone number per tree and cone size-weight distribution. The effectiveness of fertilization in increasing cone number in the long-term was not maintained for the cone sizeweight category distribution. This result could be due to the higher cone size-weight of the studied categories than values reported in Portugal and Spain, where average cone weight is lower than $350 \mathrm{~g}$ (Gonçalves and Pommerening 2012; Mutke et al. 2012). Heavier cones would impose an important nutritional demand on the tree.

Fertilization improved cone production but, in contrast to our hypothesis, it was not a response to tree growth. The combined effect of fertilization on cone number and cone size-weight led to increases in cone production from 800 to over $1500 \mathrm{~kg}$ per hectare with respect to the non-fertilized treatment; this is a very interesting result from an economic perspective.

To the best of our knowledge, this is the first longitudinal study reporting the long-term impact of fertilization on stone pine cone size-weight frequency distribution, providing useful information to determine the periodicity of re-fertilization. However, these results are only directly applicable under the edaphic conditions of the trial. Further studies are needed to find out whether refertilization of younger and older stone pine stands can be recommended for practical forestry, as well as its effectiveness on other soil conditions.

\section{Conclusions}

Positive long-term effects of fertilization were found on cone production in a stone pine plantation monitored from
16 to 25 years of age. Cone number significantly increased from 5 years after fertilization, with a peak of cone production of up to 3.3 times higher than in nonfertilized trees. Fertilization effects on cone size-weight distribution showed a positive but not long-lasting effect, with a reduction in bigger cones over the years after treatment. The key finding of this work is that fertilization has a positive impact on cone production, but only for approximately 5 years. Further assays are needed to identify the best moment to repeat fertilization.

Acknowledgements This work was supported by FONDEF, Chilean Ministry of Education (grant code D11I1134) between 2012 and 2016 and by the Chilean Ministry of Agriculture between 2017 and 2019. The authors thank Emiliano Ortega, the plantation owner, who actively collaborated with trial establishment and maintenance.

Funding information This work was supported by FONDEF, CONICYT, Chilean Ministry of Education (grant code D11I1134) between 2012 and 2016, and by the Chilean Ministry of Agriculture between 2017 and 2020.

Data availability The datasets generated and analyzed during the current study are not publicly available due to institutional guidelines, but are available from the corresponding author on reasonable request.

\section{Compliance with ethical standards}

Conflict of interest The authors declare that they have no conflict of interest.

\section{Annexes}

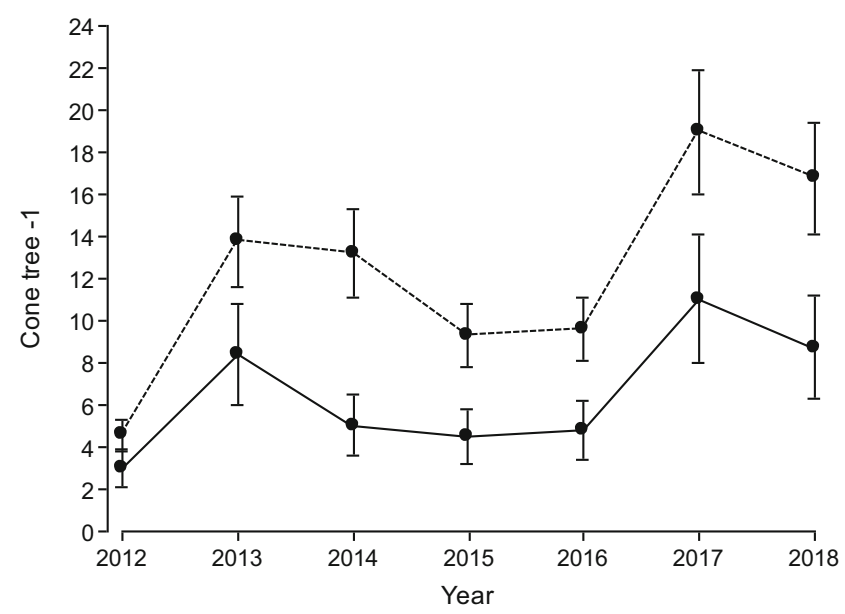

Fig. 3 Three-year-old cone production in fertilized (dashed line) and non-fertilized (solid line) trees 3 to 9 years after fertilization (2012 to 2018) in a stone pine plantation located in Toconey, central Chile. Mean \pm SE 
Table 4 Stone pine cone size-weight distribution of fertilized and non-fertilized trees between 3 and 9 years after fertilization

\begin{tabular}{|c|c|c|c|c|c|c|c|}
\hline \multirow[t]{2}{*}{ Cone size-weight category [\%] } & \multicolumn{7}{|l|}{ Year } \\
\hline & 2012 & 2013 & 2014 & 2015 & 2016 & 2017 & 2018 \\
\hline \multicolumn{8}{|l|}{ Fertilized } \\
\hline Big & $70.0 \pm 2.4 \mathrm{a}$ & $49.3 \pm 2.1 \mathrm{a}$ & $56.7 \pm 2.1 \mathrm{a}$ & $49.6 \pm 2.1 \mathrm{a}$ & $29.4 \pm 2.1 \mathrm{~b}$ & $28.7 \pm 2.0 \mathrm{~b}$ & $8.6 \pm 2.0 \mathrm{c}$ \\
\hline Medium & $25.8 \pm 2.4 \mathrm{~b}$ & $47.0 \pm 2.1 \mathrm{a}$ & $39.8 \pm 2.1 \mathrm{~b}$ & $41.7 \pm 2.1 \mathrm{~b}$ & $55.9 \pm 2.1 \mathrm{a}$ & $61.8 \pm 2.0 \mathrm{a}$ & $61.1 \pm 2.0 \mathrm{a}$ \\
\hline Small & $4.1 \pm 2.4 \mathrm{c}$ & $3.6 \pm 2.1 \mathrm{~b}$ & $3.5 \pm 2.1 \mathrm{c}$ & $8.7 \pm 2.1 \mathrm{c}$ & $14.7 \pm 2.1 \mathrm{c}$ & $9.5 \pm 2.0 \mathrm{c}$ & $30.3 \pm 2.0 \mathrm{~b}$ \\
\hline \multicolumn{8}{|l|}{ Non-fertilized } \\
\hline Big & $55.9 \pm 8.9 \mathrm{a}$ & $49.1 \pm 6.8 \mathrm{a}$ & $67.2 \pm 7.4 \mathrm{a}$ & $47.1 \pm 7.7 \mathrm{a}$ & $23.2 \pm 7.2 \mathrm{~b}$ & $19.4 \pm 7.0 \mathrm{~b}$ & $11.8 \pm 7.0 \mathrm{~b}$ \\
\hline Medium & $34.7 \pm 8.9 \mathrm{a}$ & $42.9 \pm 6.8 \mathrm{a}$ & $25.0 \pm 7.4 \mathrm{~b}$ & $38.7 \pm 7.7 \mathrm{a}$ & $54.8 \pm 7.2 \mathrm{a}$ & $65.6 \pm 7.0 \mathrm{a}$ & $62.6 \pm 7.0 \mathrm{a}$ \\
\hline Small & $9.4 \pm 8.9 \mathrm{~b}$ & $8.0 \pm 6.8 \mathrm{~b}$ & $7.8 \pm 7.4 \mathrm{~b}$ & $14.2 \pm 7.7 \mathrm{~b}$ & $21.9 \pm 7.2 \mathrm{~b}$ & $15.0 \pm 7.0 \mathrm{~b}$ & $25.5 \pm 7.0 \mathrm{~b}$ \\
\hline
\end{tabular}

Mean \pm SEM. By year, different letters indicate statistical differences $(p<0.05)$ among cone size-weight categories within treatment

\section{References}

Bento, J., Coutinho, J., 2011. Boron deficiency in stone pine. Agropine International Meeting on Mediterranean Stone pine for Agroforestry 2011/11/17-19. Valladolid, Spain

Bolling BW, Chen CYO, McKay DL, Blumberg JB (2011) Tree nut phytochemicals: composition, antioxidant capacity, bioactivity, impact factors. A systematic review of almonds, Brazils, cashews, hazelnuts, macadamias, pecans, pine nuts, pistachios and walnuts. Nutr Res Rev 24:244-275

Bussotti F (1997) Il pino domestico Pinus pinea L. (Famiglia Pinaceae). Sherwood 28:31-34

Calama R, Madrigal G, Candela JA, Montero G (2007) Effects of fertilization on the production of an edible forest fruit: stone pine (Pinus pinea L.) nuts in the south-west of Andalusia. Forest Systems 16(3): 241-252

Calama R, Conde M, De-Dios-García J, Madrigal G, Vázquez-Piqué J, Gordo FJ, Pardos M (2019) Linking climate, annual growth and competition in a Mediterranean forest: Pinus pinea in the Spanish Northern Plateau. Agric For Meteorol 264:309-321

Campelo F, Nabais C, Freitas H, Gutiérrez E (2007) Climatic significance of tree-ring width and intra-annual density fluctuations in Pinus pinea from a dry Mediterranean area in Portugal. Ann For Sci 64: 229-238

Codesido V, Merlo E (2007) Inducción floral mediante aplicación de GA 4/7 y fertilización mineral en el huerto semillero de Pinus radiata D. Don de Sergude (Galicia). Investigación Agraria: Sistemas y Recursos Forestales 16(3):262-266

Costantini E, Urbano F, L'Abate G (2004) Soil regions of Italy. [online] [Cited 16 august 2018]. Available in http://www.soilmaps.it/en/ downloads.html

Court-Picon M, Gadbin-Henry C, Guibal F, Roux M (2004) Dendrometry and morphometry of Pinus pinea L. in lower Provence (France): adaptability and variability of provenances. For Ecol Manag 194:319-333

Di Rienzo J.A., Casanoves F., Balzarini M.G., Gonzalez L., Tablada M., Robledo C.W., 2019. InfoStat version 2019. Grupo InfoStat, FCA, Universidad Nacional de Córdoba, Argentina. [online]. [Cited August 20, 2017]. Available in URL http://www.infostat.com.ar

Evaristo I, Batista D, Correia I, Correia P, Costa R (2010) Chemical profiling of Portuguese Pinus pinea L. nuts. J Sci Food Agric 90: 1041-1049
Farinha AC, Pinheiro J, Correia A, Rodrigues E, Roques A, Branco M (2018) Is Leptoglossus occidentalis entirely responsible for the high damage observed don cones and seeds of Pinus pinea? Results from a fertirrigation trial in Portugal. For Ecol Manag 429:198-206

Ferrer, A., Herrero, G., Milián, C., Aguirre, B., 2004. Carencias nutrimentales en coníferas cubanas. I Pinus tropicalis Morelet Revista Forestal Baracoa, 23 (1): 23-28

Freire JA, Rodrigues G, Tomé M (2019) Climate change on Pinus pinea L. silvicultural system for cone production and ways to contour those impacts: a review complemented with data from permanent plots. Forests 10(169). https://doi.org/10.3390/f10020169

Gonçalves AC, Pommerening A (2012) Spatial dynamics of cone production in Mediterranean climates: a case study of Pinus pinea in Portugal. For Ecol Manag 266:83-93

Hoekstra P, Mergen F (1957) Experimental induction of female flowers on young slash pine. J For 55(11):827-831

INC., 2018. Pine Nuts \& Peanuts Round Table. INC XXXVII World Nut and Dried Fruit Congress. Sevilla: International Nut and Dried Fruit Council

INTA, 2018. Series de Suelo. [online]. Available at: http://sisinta.inta. gob.ar/en/series/ [Cited January 8, 2018]

IREN-CORFO, 1964. Suelos, Descripciones proyecto aerofotogramétrico Chile/O.E.A/B.1.D. Publication $N^{\circ} 2.391 \mathrm{p}$

Kilci, M., Akbin, G., Sayman, M., Özçankaya, M., 2013. Determination of effect of fertilizing on cone yield of stone pine (Pinus pinea L.) in Kozak province. S.1.: Ege Forestry Research Institute, Technical Bulletin, $52.78 \mathrm{p}$

Kilci M, Akbin G, Sayman M, Özçankaya M (2016) Determination of effect of fertilizing on cone yield rate of stone pine (Pinus pinea L.) in Kozak province, Turkey. In: Mutke S, Correia A, Vila Verde C (eds) International Meeting on Mediterranean Stone Pine for Agroforestry 18-20 Mayo, 2nd edn. Oeiras, Portugal

Kolari, K. (ed.), 1983. Growth disturbances of forest trees. Communicationes Instituti Forestalis Fenniae, 116. 208 p

Lakatos, F., Mirtchev, S., 2014. Manual for visual assessment of forest crown condition. FAO, $17 \mathrm{p}$

Loewe MV, Venegas GA, Delard RC, González GM (2013) Thinning effect in two young stone pine plantations (Pinus pinea L.) in central southern Chile. Options Méditérr 105:49-55

Loewe MV, Balzarini M, Álvarez A, Delard C, Navarro-Cerrillo RM (2016) Fruit productivity of stone pine (Pinus pinea L.) along a climatic gradient in Chile. Agric For Meteorol 223:203-216. https://doi.org/10.1016/j.agrformet.2016.04.011 
Loewe V, Álvarez A, Balzarini M, Delard C, Navarro-Cerrillo R (2017) Mineral fertilization and irrigation effects on fruiting and growth in stone pine (Pinus pinea L.) cropping in Chile. Fruits 72(5):281-287. https://doi.org/10.17660/th2017/72.5.3

Loewe-Muñoz V, Balzarini M, Delard C, del Rio R, Álvarez A (2019a) Potential of southern Latin-American coastal areas for stone pine (Pinus pinea L.) cropping. Rendiconti Lincei. Scienze Fisiche e Naturali 30(2):379-387. https://doi.org/10.1007/s12210-01900801-z

Loewe-Muñoz V, Balzarini M, Delard C, Alvarez A (2019b) Variability of stone pine (Pinus pinea L.) fruit traits impacting pine nut yield. Ann For Sci 76:37-47. https://doi.org/10.1007/s13595-019-0816-0

Lutz M, Alvarez K, Loewe V (2016) Chemical composition of pine nut (Pinus pinea L.) grown in three geographical macrozones in Chile. CYTA - Journal of Food 15:284-290

Maggard A, Will R, Wilson D, Meek C, Vogel J (2016) Fertilization reduced stomatal conductance but not photosynthesis of Pinus taeda, which compensated for lower water availability in regards to growth. For Ecol Manag 381:37-47

Malchi, T., Shenker, M., 2011. Iron deficiency of Pinus pinea: evaluation of iron uptake mechanisms and comparison of different genetic lines. 2011. Jerusalem, Israel: s.n

Manzanera, J.A., Gómez-Garay, A., Pintos, B., Rodríguez-Rastrero, M., Moreda, E., Zazo, J., Martínez-Falero, E., García-Abril, A., 2016. Sap flow, leaf-level gas exchange and spectral responses to drought in Pinus sylvestris, Pinus pinea and Pinus halepensis iForest, 10 (1): 204-214, doi https://doi.org/10.3832/IFOR1748-009

Marschner, H., 2012. Marschner's mineral nutrition of higher plants. $3^{\text {rd }}$ Ed. S.1.: Academic Press. 672 p

McLain, R., 2008. Management guidelines for expanding Pinyon nut production in Colorado's Pinyon-Juniper woodlands. [online]. Portland, US [Cited August 20, 2017]. Available in http://www. ntfpinfo.us/docs/academicdocs/McLainFrazier2008-anagement GuidelinesPinyon.pdf

Muñoz, J.C., Gracía, F.J., 2009. Dunas litorales con Juniperus spp. In Gracía- Prieto, F.J. (Ed.). Bases Ecológicas Preliminares para la Conservación de los Tipos de Hábitat de Interés Comunitario en España. Pp. 1-61. Madrid, Spain: Ministerio de Medio Ambiente, y Medio Rural y Marino

Mutke, S., 2005. Modelización de la arquitectura de copa y de la producción de piñón en plantaciones clonales de Pinus pinea $\mathrm{L}$. Doctoral Thesis. S.1.: Universidad Politécnica of Madrid, Spain

Mutke S, Iglesias S, Gil L (2007) Selección de clones de pino piñonero sobresalientes en la producción de piña. Investigación agraria. Sistemas y recursos forestales 16(1):39-51

Mutke, S., Calama, R., González-Martínez, S., Montero, G., Gordo, J., Bono, D., Gil, L., 2012. Mediterranean stone pine: botany and horticulture. In: J. Janick (ed.), Horticultural Reviews, 39. S.1.: WileyBlackwell, pp. 153-201
Nergiz C, Dönmez I (2004) Chemical composition and nutritive value of Pinus pinea L. seeds. Food Chem 86:365-368

Paavilainen E (1990) Effect of refertilization of pine and birch stands on a drained fertile mire. Silva Fennica 24(1):83-92

Piraino S, Camiz S, Di Filippo A, Piovesan G, Spada F (2012) A dendrochronological analysis of Pinus pinea L. on the Italian midTyrrhenian coast. Geochronometria 40:77-89

Prades C, Cuevas L, Rabasco J, Martin De Almargo R, Duarte R (2005) Vecería, producción biológica y producción comercial de la piña de Pinus pinea L. en la provincia de Córdova. Revista Ciencia y Tecnología 4(82):41-50

Rapp M, Leclerc M, Lossaint P (1979) The nitrogen economy in a Pinus pinea L stand. For Ecol Manag 2(3):221-231

Ravazi S, Azizi P, Rashidi R, Keivan F (2006) The effect of NPK fertilizers on hand planting Pinus pinea in coastal areas of Caspian Sea. Iranian Journal of Natural Resources Research 59(2):377-389

Sadzawaka, R., 1990. Métodos de análisis de suelos de Chile. Serie Actas INIA N ${ }^{\circ} 16$. Santiago, Chile. $130 \mathrm{p}$

Sadzawaka, R., Carrasco, M., Grez, R., Mora, M., Flores, H., Neaman, A., 2006. Métodos de Análisis Recomendados para los Suelos de Chile. Revisión 2006. Serie Actas INIA N 34. Santiago, Chile. 164 $\mathrm{p}$

Sansavini S, Ranalli P (2012) Manuale di Ortofrutticoltura. Edagricole, Italy

Schlatter JE, Gerding V (1984) Deficiencia de Boro en Plantaciones de Pinus radiata D. Don en Chile II. Principales Causas y Corrección Bosque 6(1):32-43

Segura R, Javierre C, Lizarraga M, Ros E (2006) Other relevant components of nuts, phytosterols, folate and minerals. Br J Nutr 96(2):S36S44. https://doi.org/10.1017/BJN20061862

Shoulders E (1968) Fertilization increases longleaf and slash pine flower and cone crops in Louisiana. J For 66(3):193-197

Stroup W (2012) Generalized linear mixed models: modern concepts, Methods and Applications. CRC Press, Florida

USDA, 2004. Soil survey laboratory methods manual. Soil survey investigations report $\mathrm{N}^{\circ} 42$. Version 4.0. U.S. Department of Agriculture, Washington DC. USA, $700 \mathrm{p}$

Vanhanen L, Savage G (2013) Mineral analysis of pine nuts (Pinus spp.) grown in New Zealand. Foods 2:143-150

Vendramin G, Fady B, González-Martínez C, Sheng Hu F, Scotti I, Sebastiani F, Soto A, Petit JR (2008) Genetically depauperated but widespread: the case of an emblematic Mediterranean pine. Evolution 62(3):680-688

Zas R, Fernández-López J (2005) Juvenile genetic parameters and genotypic stability of Pinus pinaster Ait. open-pollinated families under different water and nutrient regimes. For Sci 51(2):165-174

Publisher's note Springer Nature remains neutral with regard to jurisdictional claims in published maps and institutional affiliations. 